MA MARKO B. MILETIĆ, istraživač saradnik

Institut za savremenu istoriju

Beograd, Republika Srbija

marko.miletic1990@gmail.com

originalan naučni rad

UDK: 355.48(497.1)"1941"

primljeno: 4. jul 2019.

94:355.311.5(497.1)"1941"

prihvaćeno: 20. novembar 2019.

https://doi.org/10.29362/ist20veka.2020.1.mil.65-82

\title{
BJELOVARSKA POBUNA U APRILSKOM RATU 1941. GODINE*
}

APSTRAKT: U članku se na osnovu neobjavljene arhivske građe iz Vojnog arhiva u Beogradu, objavljenih izvora koji se čuvaju u hrvatskim arhivima, relevantne memoarske $i$ istoriografske literature, prikazuje atmosfera u društvu Kraljevine Jugoslavije, s naglaskom na Bjelovar. Posebna pažnja je posvećena analizi izvođenja mobilizacije jedinica Slavonske divizije i rekonstrukciji toka pobune njenih pešadijskih pukova u vreme Aprilskog rata 1941. godine.

KLJUČNE REČI: Bjelovar, pobuna, Kraljevina Jugoslavija, Aprilski rat, Nezavisna Država Hrvatska, Slavonska divizija

\section{Uvod}

Početak zajedničkog života Srba, Hrvata i Slovenaca u novostvorenoj Kraljevini SHS bio je opterećen iskustvom bratoubilačkog rata, teškim ratnim umorom i iscrpljenošću, pre svega stanovnika predratnih kraljevina Srbije i Crne Gore, materijalnim razaranjima i nadasve velikim ljudskim žrtvama. Borbe na bojnom, ubrzo su zamenile one na političkom polju. Različita državna i istorijska svest bile su u prvim danima postojanja Kraljevine nepremostiva prepreka za postizanje dogovora, kojim je trebalo rešiti pitanje državnog uređenja. Gotovo sve hrvatske političke partije su se, shodno ideji o hrvatskom istorijskom i državnom pravu, zalagale za federalističko ili konfederalističko uređenje. ${ }^{1} \mathrm{~S}$ druge strane, srpske političke partije, kojima je takva ideja bila strana i

\footnotetext{
* Rad je deo projekta Srpsko društvo u jugoslovenskoj državi u 20. veku: između demokratije i diktature (177016), koji finansira Ministarstvo prosvete, nauke i tehnološkog razvoja Republike Srbije.

${ }^{1}$ Ovu ideju su još više pojačavali propagandni stereotipi hrvatskih političara, ,proizvedeni“ u Austrougarskoj u vreme trajanja Prvog svetskog rata, koji su smatrali da je „Hrvatska baštinik svih teritorija Dvojne monarhije“. Na tom tragu su i njihovi zahtevi „da hrvatske zemlje imaju sopstveni pravni status, pravni položaj (i) organizaciju vlasti“. Љубодраг Димић, Срби и Југославија - простор, друштво и политика (Београд: Стубови културе, 1998), 31, 116. О odnosu između ideje hrvatskog državnog prava i stvaranja Jugoslavije više u: Mirjana Stefanovski, Ideja hrvatskog državnog prava i stvaranje Jugoslavije (Beograd: Draganić, 1995).
} 
koje su se vodile idejom „o narodnom i državnom jedinstvu“ “, zalagale su se za unitarizam i centralizam. ${ }^{3}$ Prevaga ovog drugog principa manifestovana je donošenjem Vidovdanskog ustava. Način na koji je on donet „otvorio je tkz. hrvatsko pitanje i doprineo nastajanju nezadovoljstva u hrvatskim masama“. 4

Hrvatsko pitanje je postalo okosnica sveukupnog političkog života Kraljevine Jugoslavije. Stanje permanentnog političkog sukoba dovodilo je s vremena na vreme do zapaljive atmosfere i pretilo je da ugrozi opstanak jugoslovenske kraljevine. Hrvati su sve manje Kraljevinu Jugoslaviju osećali kao svoju državu, a sve više kao neki vid okupacije. O tome najbolje svedoče izjave vođe hrvatskog naroda u Kraljevini Jugoslaviji, Vlatka Mačeka. Naime, u toku 1937. i 1938. Maček je imao nekoliko javnih istupa prema inostranstvu. On je prvo britanskom političaru Sitonu Votsonu kazao da ,nije siguran da bi se mase narodne tukle protiv Italije, ako njihovim (hrvatskim - prim. aut.) nacionalnim aspiracijama ne bude udovoljeno". ${ }^{5}$ Zatim je u razgovoru sa češkim diplomatom dr Hubertom Ripkom izneo tvrdnju da bi u „Hrvatskoj na početku rata nastala onakva pasivnost kakva je vladala na kraju Austrougarske“. ${ }^{6}$ Najoštriji u ovim verbalnim istupima bio je u izjavi koju je dao atašeu za štampu Čehoslovačkog poslanstva, kada je rekao: „Pitanje je, da li je mobilizacija u Hrvatskoj uopće moguća. Ja mislim nipošto. Ako bismo već morali uzeti pušku u ruku, prešli bismo na drugu stranu. Nije važno kome bismo prešli. Nije važno na kojoj bi se strani borio Beograd. Prebjegli bismo, makar i Nijemcima, premda ih ne volimo".?

Knez Pavle je pokušao da pregovorima, koji su na kraju rezultirali stvaranjem Banovine Hrvatske, ovakvo stanje ublaži, ali je za to bilo dockan. Atmosfera razdora između Srba i Hrvata nije se mogla popraviti tako brzo, a posledice dvadesetogodišnje političke borbe nisu se mogle izbrisati nikakvim sporazumom ili vladinim dekretom. Pišući o tome general Petar Nedeljković, komandant Četvrte armijske oblasti i ratne Četvrte armije, zabeležio je: „Kroz 20 godina rezistencije, hrvatski narod je bio odstranjen od saradnje za izgradnju

\footnotetext{
2 Slobodan Jovanović je to opisao na sledeći način: „U svojoj vekovnoj borbi za državnu samostalnost, Srbi su dobili pravi kult državne ideje i dosta je bilo da im se kaže da federalizam može dovesti u pitanje državno jedinstvo, pa da oni odmah postanu njegovi protivnici“. Слободан Јовановић, Југословенска мисао у прошлости и будућности (Београд: Слобода, 1939), 3.

${ }^{3}$ Srpski političari, koji su verovali da je činom ujedinjenja ostvaren san o okupljanju svih Srba u jednoj državi, ali i svesni velike etničke izmešanosti stanovništva, smatrali su da će „istrajavanje na ideji „etničkog jedinstva“ i centralističkom uređenju neminovno ubrzati proces integracije naroda koji su otpočinjali zajednički život". Љубодраг Димић, Историја српске државности. Књига 3 - Србија у Југославији (Нови Сад: Српска академија наука и уметности - Огранак у Новом Саду, Беседа, Друштво историчара јужнобачког и сремског округа, 2001), 108.

${ }^{4}$ Ивана Добривојевић, „Прилог проучавању сучељених перцепција. Хрвати и Срби о Краљевини Југославији“, Токови историје, бр. 3, (2009), 190.

5 Citirano prema: Mira Radojević, „Demokratska stranka o državnom preuređenju Kraljevine Jugoslavije 1935-1939“, Istorija 20. veka, br. 1-2, (1991), 42.

${ }^{6}$ Citirano prema: Ljubo Boban, Maček i politika HSS 1928-1941. Iz povijesti hrvatskog pitanja, I-II (Zagreb: Liber, 1974), I/247.

${ }^{7}$ Izveštaj Poslanstva Čehoslovačke Republike u Beogradu, br. 1454 od 6. decembra 1937, u: Lj. Boban, n. d., I/315-316.
} 
države i činjeno je sve da se ugled države unizi, da se vera u njeno postojanje ubije, da se vlasti ne poštuju, radi čega je nastalo pravo bezvlašće, (što) se porazno odražavalo i na samu vojsku“. Zbog toga je on u svojim izveštajima upozoravao jugoslovenski vojni vrh ,da se hrvatski narod u masi neće boriti ako dođe do rata" (istaknuto u originalu - prim. aut.). ${ }^{8}$

I na mikro planu, tj. na prostoru Bjelovara ovakva atmosfera je bila vidljiva. Na maloj teritoriji preplitale su se različite ideologije i interesi. Rad ustaša, četničkih društava, ali i državnih organa doprineo je stvaranju ,naelektrisane" atmosfere, koja je u nekoliko navrata dovela i do gubitka ljudskih života.

Delovanje ustaškog pokreta na prostoru Bjelovara, jugoslovenske vlasti pratile su još od 1935. godine. Hrvatski istoričar Zdravko Dizdar ističe da postoje određeni podaci koji govore o tome da je grupa desnog krila HSS-a u prisustvu Mila Budaka u Bjelovaru položila ustašku zakletvu, te da je tom prilikom „,bila dogovorena daljna djelatnost za rušenje Jugoslavije i stvaranje nezavisne hrvatske države“. Bjelovarske ustaše su uputstva za rad, letke i drugi propagandni materijal dobijali od ustaškog vođstva u Zagrebu. Kao poverenici glavnog ustaškog stana u Bjelovaru tokom februara 1941. naznačeni su Mija Hans, Julije Makanec i Martin Horvatić. Do početka rata na prostoru bjelovarskog kotara bilo je oko 50 ustaša i oko 100 njihovih simpatizera. Dizdar takođe ističe i antihrvatske akcije četničkih društava i državnih organa na prostoru Bjelovara, i iznosi zaključak da su i one doprinele porastu ,neprijateljstva Hrvata prema vlastima i državi““. ${ }^{9}$ U ovakvoj unutrašnjoj političkoj atmosferi, Kraljevina Jugoslavija i Bjelovar dočekali su početak Aprilskog rata.

\section{Mobilizacija Slavonske divizije}

Na prostoru Banovine Hrvatske postojale su dve armijske oblasti - Četvrta i Primorska. Četvrta armijska oblast delila se na Savsku, Mursku i Osiječku divizijsku oblast. Ovoj potonjoj je, između ostalog, pripadao Bjelovarski vojni okrug, na čijoj teritoriji je bio dislociran 42. pešadijski puk (bez jednog bataljona). ${ }^{10}$

Sve zvučnije zveckanje oružjem u drugoj polovini 1930-ih nateralo je jugoslovenski vojni vrh da preduzme niz mera koje su za cilj imale pripremu zemlje za eventualni rat. Na tom tragu možemo pratiti i povremena aktiviranja jedinica, koja su započela u drugoj polovini 1938. godine, a nastavila se sve do početka Aprilskog rata. Tako je početkom 1941. u Bjelovaru aktiviran i 108. pešadijski puk.

Posle puča od 27. marta 1941, naređeno je aktiviranje celokupne vojske koje je trebalo da počne 3. aprila. Na prostoru Bjelovarskog vojnog okruga trebalo

\footnotetext{
${ }^{8}$ Vojni arhiv (VA), Popisnik 17 (P17), k.(utija) 8a, f.(ascikla) 2, dok.(ument) 38, Izjava armijskog generala Petra Nedeljkovića, 1.

${ }^{9}$ Zdravko Dizdar, „Bjelovarski ustanak od 7. do 10. travnja 1941“, Časopis za suvremenu povijest, br. 3, (2007), 583-587.

${ }^{10}$ VA, P17, k. 4, f. 1, dok. 9, Izjava generala Milivoja Alimpića, 2. Zdravko Dizdar navodi da se preostali bataljon nalazio u Koprivnici, dok komandant Osiječke divizijske oblasti u svojoj izjavi kaže da se on nalazio u Slavonskoj Požegi.
} 
je formirati Slavonsku diviziju u koju su, pored pominjanih 42. i 108. pešadijskog puka, trebali da uđu i 40. dopunski peš. puk, zatim 17. artiljerijski puk iz Petrinje, 89. pešadijski puk iz Siska, kao i 40. konjički divizion. Popunjenost ovih jedinica ljudstvom i stokom je varirala. Tako se u 42. peš. puku do pokreta na koncentracijsku prostoriju javila tek polovina predviđenog ljudstva, ali je odziv komore bio izuzetno loš, pa je koncentracijski pokret ovog puka dolazio u pitanje. ${ }^{11}$ Dopunski 40. peš. puk, iz iste divizije, po izjavi kapetana Ivana Mraka bio je popunjen sa $47 \%$ ljudstva i tek $3 \%$ stoke, ${ }^{12}$ dok je najbolje bio popunjen 108. peš. puk. ${ }^{13}$

Kada govorimo o mobilizaciji i odzivu obveznika na ovom prostoru moramo istaći i jednu vrlo važnu okolnost o kojoj u dosadašnjoj istoriografiji, kako jugoslovenskoj, tako i srpskoj i hrvatskoj, nije bilo reči. Dvojica jugoslovenskih oficira, naime, iznose podatke da se $u$ dve jedinice koje su formirale Slavonsku diviziju nisu pozivali obveznici Srbi. Prvi od njih, kapetan I klase Dušan Šešlija, u ratu komandir 3. mitraljeske čete 108. peš. puka, napisao je da je za to najpre čuo od trgovca Petra Vukadinovića iz sela Vulinca, a da se kasnije i sam u to uverio uvidom u spiskove pozvanih. ${ }^{14}$ Drugi, major Dobroslav Krstić, u ratu komandant jednog bataljona 40. dopunskog peš. puka, piše da je prilikom izrade spiskova obveznika koji nisu došli uvideo da obveznici Srbi nisu ni pozivani. ${ }^{15}$ Indikativno je to da u trenutku pisanja svojih sećanja na ove događaje oni nisu mogli znati za tekst ovog drugog. Nažalost, u raspoloživoj građi nismo uspeli da nađemo i dokument koji bi dodatno potvrdio ove njihove iskaze. Međutim, ako navedeno stavimo u kontekst toga da su organizatori kasnije pobune u Bjelovaru, među kojima je prednjačio narednik Ivan Čvek, nagovarali hrvatske rezerviste da se odazovu pozivu za aktiviranje i prime oružje s kojim će u ,pogodnom trenutku, uz pomoć Nijemaca i Talijana prognati Srbe“ ${ }^{16}$ možemo pretpostaviti da iskazi dvojice oficira ipak imaju osnova, tim pre što je u bjelovarskom kotaru pred rat živelo oko $20 \%$ Srba, te bi pobunu bilo daleko teže sprovesti u prisustvu većeg broja obveznika srpske nacionalnosti.

\section{Pobuna}

Slavonska divizija je zajedno sa Savskom i Murskom divizijom, te Ormoškim odredom činila Četvrtu armiju, koja je dalje sa Sedmom armijom činila Prvu grupu armija Vojske Kraljevine Jugoslavije. Poslednje pobrojana je po odredbama ratnog plana „,R-41“ trebalo da posedne i brani granični front od Dravske Moslavine na istoku, duž granice sa Mađarskom, Nemačkom i Italijom sve do Karlobaga na moru. Odbranom ovog dela graničnog fronta ona je trebalo da zaštiti levo krilo i bok celokupnog rasporeda preostalih jugoslovenskih snaga i spreči

\footnotetext{
${ }^{11}$ VA, P17, k. 5, f. 1, dok. 15, Izjava divizijskog generala Ratka Raketića, 2.

${ }^{12}$ VA, P17, k. 67, f. 11, dok. 1221, Izjava kapetana Ivana Mraka, 1.

${ }^{13}$ VA, P17, k. 8, f. 1, dok. 19, Izjava pešadijskog poručnika Stanislava Rapoteca, 1.

${ }^{14}$ VA, Popisnik 16 (P16), k. 49, f. 1, dok. 22, Izjava kapetana Dušana Šešlije, 1.

15 Драгослав С. Крстић, „Бјеловар 1941. - из мог ратног дневника“, Гласник СКИД „Његош", св. 23, (1969), 33.

${ }^{16}$ Z. Dizdar, n. d., 588.
} 
prodor neprijatelja u dolinu Save. U daljim operacijama, Prva grupa armija trebalo je da se prikupi na desnim obalama reka Save i Kupe. ${ }^{17}$ Slavonska divizija se nalazila na krajnjem desnom krilu, sa zadatkom da posedne i brani položaje duž reke Drave od Dravske Moslavine do sela Kloštara (zaključno). ${ }^{18}$

Napad Nemačke na Kraljevinu Jugoslaviju otpočeo je noću 5/6. aprila 1941. godine. Cilj prvog, prepadnog napada bio je zauzimanje Sipskog kanala, koji je od strane nemačke vojne komande obeležen kao ključna tačka Đerdapske klisure. ${ }^{19}$ Glavni napad, kako kopnenih tako i vazduhoplovnih snaga, ipak je otpočeo u zoru 6. aprila. Dok je Beograd bio glavni cilj nemačkog ratnog vazduhoplovstva, na najjačem udaru nemačkih kopnenih snaga našle su se jedinice Treće grupe armija, tačnije Trupe Treće armijske oblasti, koje su štitile front na makedonsko-bugarskoj granici od Dojranskog jezera na jugu do sela Žeravino na severu. ${ }^{20} \mathrm{Na}$ ostalim graničnim odsecima prvog dana rata napadi su bili znatno slabiji ili ih uopšte nije ni bilo. ${ }^{21}$ Jedinice Slavonske divizije tog dana izvršavale su i dalje koncentracijske pokrete i nisu bile uznemiravane od strane neprijatelja. Borbe su vođene severozapadno od njenih položaja, na području Prekomurja, ${ }^{22}$ kao i na teritoriji Dravske banovine. ${ }^{23}$

Uspesi koje je nemačka Druga armija postigla u toku 6. aprila, u borbama u Prekomurju i Dravskoj banovini, uslovili su da njen 46. armijski korpus dobije zadatak da 7. aprila na prepad zauzme mostove kod Koprivnice (Đekenješa) i kod Barča i da na odseku između ova dva mesta formira mostobran. U komandi Druge armije nemačke vojske, tom prilikom dat je veći značaj zauzimanju mostova kod Barča. ${ }^{24}$ Već oko pet časova izjutra 7. aprila Nemci su sa dva bataljona u gumenim čamcima uspeli da pređu Dravu u rejonu Đekenješa. Most koji je trebalo da zauzmu bio je srušen, ali je za njih povoljna okolnost

${ }^{17}$ VA, P17, k. 5, f. 1, dok. 5, Izjava armijskog generala Milorada Petrovića, 11-12.

${ }^{18}$ VA, P17, k. 8a, f. 2, dok. 38, Izjava armijskog generala Petra Nedeljkovića, 8.

${ }^{19} \mathrm{O}$ strategijskom značaju Dunava i Đerdapa, kao i nemačkom napadu na Sipski kanal više u: Milan Gulić, „Važnost Dunava i Đerdapa u ratnim operacijama na području Jugoslavije 19411944“, Istorija 20. veka, br. 3, (2012), 37-62. O nemačkom napadu na Sipski kanal videti još u: Nikola Račić, Istočna Srbija u ratu i revoluciji 1941-1945 (hronologija) (Zaječar: Međuopštinska konferencija SKS, Istorijski arhiv Timočke krajine, 1984); Velimir Terzić, Slom Kraljevine Jugoslavije 1941. Uzroci i posledice poraza, I-II (Beograd, Ljubljana, Podgorica: Narodna knjiga, Partizanska knjiga, Pobjeda, 1982).

20 O operacijama na ovom delu fronta više u: Marko B. Miletić, „Pokušaj odbrane istočne Makedonije u Aprilskom ratu 1941“, Vojnoistorijski glasnik, br. 1, (2015), 238-262.

${ }^{21} \mathrm{O}$ operacijama na ostalim graničnim odsecima u toku 6. aprila više u: V. Terzić, $n$. $d$.; Drugi svetski rat (pregled ratnih operacija). Događaji od početka rata do 22. juna 1941 (Beograd: Vojnoistorijski institut JNA, 1957).

${ }^{22}$ VA, P17, k. 8a, f. 2, dok. 38, Izjava armijskog generala Petra Nedeljkovića, 11; VA, P17, k. 9, f. 3, dok. 149, Izjava Gruja Božičkovića, 2; V. Terzić, $n$. d., II/299.

${ }^{23} \mathrm{O}$ operacijama na prostoru Dravske banovine više u: Marko B. Miletić, „Dravska banovina u Aprilskom ratu 1941. godine“, Prispevki za novejšo zgodovino, 2, (2018), 85-109.

${ }^{24}$ Aprilski rat 1941, Zbornik dokumenata, knjiga 2, prir. Antun Miletić (Beograd: Vojnoistorijski institut, 1987) - dok.(ument) br. 159: Zapovest nemačke 2. armije od 6. aprila 1941. potčinjenim korpusima da se drže dostignutih linija i obrazuju mostobran preko Drave na odseku Koprivnica - Barč, 479-480. 
bila ta što to nije učinjeno na adekvatan način. ${ }^{25}$ Pošto su prešle Dravu nemačke jedinice su vrlo brzo uspele da sa prostora selo Sigetec - Botovo potisnu 1. bataljon 53. peš. puka Savske divizije, koji je prethodnog dana zauzeo ovaj položaj, te tako formiraju mostobran na desnoj obali ove reke, čime su za kratko vreme ispunili jedan od postavljenih zadataka. ${ }^{26}$ Preostali deo dana na ovom pravcu prošao je u borbama između nemačkih i jedinica Savske divizije. ${ }^{27}$

Dok su se jedinice Savske divizije nalazile u borbenim dejstvima, situacija na delu fronta koji je zatvarala Slavonska divizija bila je mirna. Ipak, do komande divizije iz sela Terezino Polje stizali su preko dana izveštaji da se neprijatelj prikuplja kod Barča. Iz tog razloga izdato je naređenje da se poruše železnički i drumski most kod tog mesta. Da koncentracija nemačkih snaga kod Barča nije bila bez razloga, postalo je jasno u 19.00 časova, kada su Nemci otpočeli artiljerijsku pripremu za napad. ${ }^{28}$ Ubrzo posle prvih artiljerijskih plotuna začula se jaka eksplozija, što je bio znak da je porušen železnički most. Prisutni jugoslovenski vojnici očekivali su još jednu eksploziju, koja bi označila rušenje drumskog mosta, ali do nje nije došlo. Most je ostao neporušen, pa su nemački vojnici oko 20.15 časova prešli preko njega. ${ }^{29}$ Jugoslovenski vojnici iz sastava 2. bataljona 393. puka rezervne vojske, koji su se nalazili u blizini neporušenog drumskog mosta, otpočeli su povlačenje u pravcu Virovitice već $u$ 20.30 časova,$^{30}$ ostavljajući u utvrđenim bunkerima naoružanje i municiju. ${ }^{31}$ Pošto na ovom prostoru nije bilo operativnih jedinica iz sastava Slavonske divizije, izuzev 40. konjičkog diviziona, nemačke jedinice su do 23.15 časova, bez većih sukoba, uspele da obrazuju mostobran u visini sela Gornje Bazje. ${ }^{32}$

Ubrzo posle vesti o nemačkom zauzimanju mosta kod Barča, u 02.45 časova, načelnik štaba Slavonske divizije major Lončarić obavestio je generala Nedeljkovića da se 108. peš. puk Slavonske divizije pobunio i da je krenuo nazad ka Bjelovaru. ${ }^{33}$

${ }^{25}$ Velimir Terzić u svojoj monografiji Slom Kraljevine Jugoslavije 1941, piše da su nemačke jedinice prešle Dravu kod Đekenješa ,preko neporušenog mosta i (u) gumenim čamcima“ (V. Terzić, $n$. $d$., II/312). Ipak, ni u jednom dostupnom izvoru, počevši od izjave generala Augusta Marića, preko Operacijskog dnevnika Četvrte armije, sve do Operacijskog dnevnika Štaba Vrhovne komande, ne možemo naći potvrdu takvog zaključka, tj. tvrdnje da most kod Đekenješa nije srušen. U najnepovoljnijem slučaju možemo pronaći informacije da most nije srušen u potpunosti.

${ }^{26}$ VA, P17, k. 4, f. 1, dok. 38, Izjava divizijskog generala Augusta Marića, 10; VA, P17, k. 5, f. 1, r. b. 5, Izjava armijskog generala Milorada Petrovića, 18; Aprilski rat 1941, ZD, knj. 2, Prilog br. 1: Operacijski dnevnik Štaba Vrhovne komande JV, 816; Mile Bjelajac, „Savska divizija u Aprilskom ratu“, Vojnoistorijski glasnik, br. 1, (1991), 137; V. Terzić, n. d., II/312.

${ }^{27} \mathrm{O}$ operacijama Savske divizije u Aprilskom ratu više u: M. Bjelajac, $n$. $d$., $125-158$.

${ }^{28}$ U svim izvorima izuzev onog koji nosi naziv Slavonska divizija (VA, P16, k. 49, f. 1, dok. 11, Slavonska divizija, 2), kao početak nemačkog napada navodi se vreme oko 19.00 časova. Jedino u ovom izvoru kao početak nemačkog napada stoji 16.50 časova. Odlučili smo da damo poverenje većem broju izvora i da kao vreme nemačkog napada označimo 19.00 časova.

${ }^{29}$ VA, P17, k. 8a, f. 2, dok. 38, Izjava armijskog generala Petra Nedeljkovića, 14.

${ }^{30}$ VA, P16, k. 49, f. 1, dok. 25, Izjava majora Save Filipovića, 1.

${ }^{31}$ VA, P17, k. 8a, f. 2, dok. 38, Izjava armijskog generala Petra Nedeljkovića, 15.

${ }^{32}$ Isto, 14; V. Terzić, $n$. d., II /316.

${ }^{33}$ VA, P17, k. 8a, f. 2, dok. 39, Operacijski dnevnik Četvrte armije, 10. 
Pripreme za pobunu počele su ranije. Narednik Čvek je dajući izjavu o svom učešću u ovim događajima rekao da su on i njegovi saradnici ,odlučili onemogućiti Srbima davanje otpora u našim krajevima“, mada nije precizirao način na koji su to hteli učiniti. Put koncentracijske prostorije, 108. peš. puk krenuo je 5. aprila. Tom prilikom municija nije podeljena hrvatskim rezervistima iz straha od pobune. Uprkos tome, Čvek je uspeo da preko svojih saradnika podeli oko 6.000 metaka ,pouzdanim“ Hrvatima. Oni su odlučili da će čim se Nemci približe tom municijom pobiti sve oficire Srbe, uzeti svu preostalu municiju i naoružanje i vratiti se u Bjelovar, u kome su ustaše Mijo Hans i Ivan Šestak vršili pripreme za pobunu, uz saradnju sa gradonačelnikom Bjelovara Julijem Makancem. Uz to Čvek i njegovi saradnici su u toku koncentracijskog nastupanja neprestano širili razne glasine, ${ }^{34}$ kako bi na taj način što više uznemirili vojnike. ${ }^{35}$

Pošto su nemačke jedinice uveče 7 . aprila nešto posle 20.00 časova prešle Dravu kod Barča, vojnicima 108. peš. puka podeljena je municija i naređeno im je da iz Velikog Grđevca gde su se nalazili krenu put Virovitice. Prvo se pobunio 3. bataljon kome je naređeno da posedne severnu ivicu pomenutog mesta. U trenutku kada je bataljon trebalo da krene, neko je viknuo: „Stoj! Nigdje ne idemo! Živio Pavelić! Natrag u Bjelovar!“ Zatim se čula puščana vatra koja je bila dogovoreni znak za početak pobune, a onda i povici: „Živjela Hrvatska, nećemo na front - hoćemo nazad za Bjelovar" i pesma „Vilo Velebita“. Posle ovoga nastalo je opšte rasulo i bežanija, prvo kod ovoga, a zatim i kod ostalih bataljona. Čete su počele da otkazuju poslušnost, a to je uradila i 3 . mitraljeska četa narednika Čveka. ${ }^{36}$ Komandant puka potpukovnik Vojislav Petrović $^{37}$ zarobljen je sa delom štaba, u kome je ostalo svega oko 50 vojnika, podoficira i oficira u školskoj zgradi u selu Kovačica, ${ }^{38}$ deo oficira je uspeo da

${ }^{34}$ Glasine su bile različite, od toga da se ide na bugarski front, preko toga da im Bosanska divizija neće doći kao pojačanje, do toga da se 108. peš. puk prvi šalje u borbu kako bi najviše stradao.

35 Željko Karaula, prir., Bjelovarski ustanak 7.-10. travnja 1941. u povijesnim izvorima Dokumenti, (Bjelovar: Viatoni, 2012) - dok. br. 48: Članak Ivana Čveka u listu Hrvatski domobran o ustanku u Bjelovaru „Kako su Ustaše u Bjelovaru uspostavili red i mir, te raspršili srpsku vojsku“, 91-93; Z. Dizdar, $n$. d., 588-590.

${ }^{36}$ U pisanoj izjavi o događajima u Bjelovaru datoj 30. aprila 1942. narednik Čvek je zapisao: „Kako je situacija bila jasna nato je moja četa 3. mitraljeska otkazala poslušnost, i bez da je ma koji pobjegao, prije napunila puške i kada smo trebali krenuti za Viroviticu odgovorili su vojnici. Sa Bjelovara opalilo je oko 50 pušaka našta je dotrčao komandant pješadije Kragujević i pokušavao povratiti sa riječima da je dr Maček na vladi i da on traži borbu sa Nijemcima, a našto su vojnici odgovorili da ne poznaju oni više Mačeka, nego Slobodnu Državu Hrvatsku i glasno vikali ostalim četama: hodite napried za Bjelovar, našta je krenula prva moja 3. mitraljeska četa na čelu, koja je kasnije otišla pozadi, kada su stigle ostale streljačke satnije [čete - prim. aut.]“. Ž. Karaula, Bjelovarski ustanak - Dokumenti - dok. br. 52: Izviješće vođe „bjelovarskog ustanka“ narednika Ivana Čveka o travanjskim danima u Bjelovaru i okolici, 103.

37 Zdravko Dizdar u svom radu o bjelovarskoj pobuni na dva mesta pominje izvesnog „potpukovnika Kragujevića“" kao komandanta 108. peš. puka (Z. Dizdar, n. d., 590-591). On tu greši jer je komandant 108. peš. puka bio potpukovnik Vojislav Petrović, dok je Milan Kragujević bio brigadni general i komandant pešadije Slavonske divizije, koji je za malo uspeo da izbegne zarobljavanje i pobegne iz škole u Kovačici.

${ }^{38}$ Kapetan Dušan Šešlija, komandir 3. mitraljeske čete u kojoj je bio i narednik Ivan Čvek, dao je u 
pobegne, a deo njih je pobijen. Među ovim poslednjim bio je i kapetan Jakša Novaković, komandir divizijske bojne komore, koji je sa revolverom u ruci branio magacin sa municijom. ${ }^{39}$

Nakon što su zarobili komandanta puka, pobunjenici su oko 22.30 krenuli iz Kovačice pravcem ka Bjelovaru. Nešto posle ponoći kolona je stigla u selo Grđevac, gde je i prenoćila. Komandu nad pobunjenicima iz 108. peš. puka preuzeli su narednik Ivan Čvek, narednik-đak Milan Šepak i podnarednik Vilim Retković. Pokret je nastavljen ujutru u 6.00 časova, pravcem Grđevac-SeverinBjelovar. Pobunjenička kolona podeljena je na tri dela. Prethodnicu, kojom je komandovao narednik-đak Šepak, zatim glavninu kojom je komandovao narednik Čvek i na kraju zaštitnicu i trupnu komoru kojim je komandovao podnarednik Retković. ${ }^{40}$ Čvek i Šepak su razmatrali i opciju da pobunjenička kolona

svojoj izjavi opis zarobljavanja komandanta 108. peš. puka. „Rulja [delovi pobunjenog 4. bataljona 108. peš. puka] je stala pred školsku zgradu i počela da viče: „U Bjelovar, u Bjelovar, nećemo bez oficira i oficiri sa nama u Bjelovar!“ Komandant puka je otvorio prozor i pojavio se pred ruljom. Pozvao ih je da se umire, da ne zaborave zakletvu datu Kralju i Otadžbini, a on im obećava da će on odmah ići sa svim oficirima i sa njima da brani otadžbinu. Gomila je počela da viče: „Nećemo, hoćemo u Bjelovar, vi ste nas doveli, vi ćete sa nama - natrag!“ Komandant je na to odgovorio da oni mogu ići u Bjelovar, a mi ćemo oficiri sami ići da se borimo sa neprijateljem. Zatim je počela pucnjava pobunjenika na školu. Jedan ordonans koji je bio pored zaključanih vrata, ranjen je u glavu. Oficiri, koji su do tog trenutka bili u prostoriji, istrčali su sa komandantom pešadije [komandant pešadije Slavonske divizije, brigadni general Milan Kragujević] na zadnja vrata, školska, u dvorište, a odatle u zabran iza školskog dvorišta, gde su zaštićeni mrakom mogli da se sklone od pobunjenika. Pobunjenici zadnjem delu zgrade još dugo nisu smeli da priđu jer su smatrali da su mitraljezi još tu [Ranije u toku večeri, mitraljezi su bili postavljeni ispred zadnjeg ulaza, ali su brzo uklonjeni, što pobunjenici nisu znali]. Komandant puka sa 2-3 ordonansa ostao je sam u zgradi, zaključao je zadnja vrata. [...] Pucnjava se čula svuda oko škole. Zvali su komandanta da izađe, pokušavali su da razbiju vrata. [...] Komandanta puka pozvali su da izađe, da mu se ništa neće desiti samo mora sa njima u Bjelovar. Komandant je i dalje tražio da njega ostave na miru, a oni neka sami idu - produže za Bjelovar. Na to su pobunjenici počeli da razbijaju. Na to sam ja javio komandantu da su rulje svuda oko škole. Komandant je zapretio pobunjenicima da će pucati, ali oni su prodrli u školu i izveli komandanta. Oslovljavali su ga sa ,gospodine potpukovniče“, oružje mu nisu oduzeli. Pobunjenici su pretražili celu školu, da li se još koji od oficira nije sklonio. Jedan od pobunjenika izneo je pukovsku zastavu, hteli su da je razviju“. VA, P16, k. 49, f. 1, r. b. dok. 22, Izjava kapetana Dušana Šešlije, 23-27.

39 VA, P17, k. 8, f. 1, dok. 19, Izjava poručnika Stanislava Rapoteca, 2; VA, P17, k. 67, f. 11, dok. 1221, Izjava kapetana Ivana Mraka, 1; VA, P16, k. 49, f. 1, dok. 22, Izjava kapetana Dušana Šešlije, 21-25; Ž. Karaula, Bjelovarski ustanak - Dokumenti - dok. br. 52: Izviješće vođe „bjelovarskog ustanka“ narednika Ivana Čveka o travanjskim danima u Bjelovaru i okolici, 103; V. Terzić, $n$. d., II/333; Z. Dizdar, $n$. d., 590.

${ }^{40}$ Vazduhoplovni kapetan Ivan Mrak u svojoj izjavi pominje i snagu ovih kolona. Po njegovim rečima, prethodnica je bila jačine jednog bataljona, a glavnina jačine tri bataljona. O snazi zaštitnice on ne daje podatke. Moramo biti oprezni prilikom analize ovih podataka zato što je veliki deo vojnika iz 108. peš. puka iskoristio metež i pobegao svojim kućama, tako da pomenuti bataljoni nisu bili popunjeni do punog formacijskog sastava. Nemamo izvorno utemeljenje, ali možemo pretpostaviti da se vojnici koji su ostali u pobunjeničkoj koloni nisu među sobom mešali, već da su ostali u formacijskim jedinicama u kojima su bili i pre pobune, što bi značilo da četiri bataljona koje pominje kapetan Mrak postoje, ali da je njihovo brojno stanje redukovano u odnosu na broj ljudstva koje podrazumeva bataljon u punom formacijskom sastavu VA, P17, k. 67, f. 11, dok. 1221, Izjava kapetana Ivana Mraka, 1. 
krene za Đurđevac, te da se na Bilogori zauzme položaj u cilju da se što pre uhvati veza sa Nemcima kako bi im se stavili na raspolaganje za zajedničku akciju protiv, kako su njih dvojica smatrali, „,srpskih“ jedinica. Međutim, zbog nemogućnosti da provere kakvo je stanje na terenu, tj. da utvrde da li su nemačke jedinice na mestima na kojima su ih oni očekivali, od ove ideje se odustalo i nastavljen je put pravcem prema Bjelovaru. Prolazeći kroz sela nastanjena većinskim hrvatskim stanovništvom, masa je oduševljeno pozdravljala kolonu, uzvikujući parolu „Živjela Hrvatska!““.41

U istoj noći kada se pobunio 108. peš. puk u Velikim Grđevcima, pobunio se i 40. dopunski peš. puk u Severinu. Vojnici iz ove jedinice uspeli su u toku noći da se dokopaju municije i da u zoru, podstaknuti nekim vojnicima iz 108. peš. puka, organizuju pobunu. Pobunjenici su uspeli da zarobe komandanta puka, potpukovnika Ljubomira Sakovića sa štabom, kao i komandante dva bataljona, majore Krstića i Mandića. Na čelu pobunjenog puka našao se poručnik Leopold Suplančić. U toku 8. aprila dva pobunjena puka su se spojila i udruženim snagama krenula put Bjelovara. Na tom putu priključio im se i deo vojnika iz sastava 42. peš. puka. ${ }^{42}$

Pošto je saznao za pobunu 108. peš. puka, general Nedeljković je u svoj štab pozvao vršioca dužnosti načelnika okruga Josipa Verhasa i komandira žandarmerijske čete u Bjelovaru, kapetana Ćirila Petrovara. Njima dvojici, general Nedeljković je izjutra 8. aprila oko 3.30 časova naredio da izdaju policiji i žandarmeriji potrebna uputstva za održavanje reda u gradu, što su oni i učinili. Prilikom sastanka u štabu armije, kapetan Petrovar je kazao generalu Nedeljkoviću da je za loš moral i raspoloženje obveznika bjelovarskog vojnog okruga kriva ustaška propaganda, te da zbog nje seljaci neće da idu u rat nego hoće da ostanu kod svojih kuća. Pored toga, on je izrazio nesigurnost u spremnost žandarmerije i policije da se bore protiv pobunjenika. Nakon razgovora sa njima general Nedeljković je doneo odluku da štab armije premesti iz Bjelovara u selo Popovaču, a da u Bjelovaru ostane major Vojislav Topalović radi održavanja veze, sve dok štab armije ne stigne u novo komandno mesto, nakon čega je $\mathrm{i}$ on trebalo da napusti Bjelovar. ${ }^{43}$

Da je odluka o premeštanju štaba iz Bjelovara bila ispravna, pokazalo se već oko 7.00 časova. Tada su u Bjelovar ispred štaba Četvrte armije stigla dva kamiona sa pobunjenicima iz 108. peš. puka sa zadatkom da ga unište. Straža štaba je po naređenju potpukovnika Dušana Đurića otvorila vatru na pobunjeni-

${ }^{41}$ VA, P16, k. 49, f. 1, dok. 22, Izjava kapetana Dušana Šešlije, 27-33; VA, P17, k. 67, f. 11, dok. 1221, Izjava kapetana Ivana Mraka, 1; Ž. Karaula, Bjelovarski ustanak - Dokumenti, dok. br. 52: Izviješće vođe „bjelovarskog ustanka“ narednika Ivana Čveka o travanjskim danima u Bjelovaru i okolici, 103; V. Terzić, n. d., II/333; Z. Dizdar, n. d., 590-591.

${ }^{42}$ VA, P17, k. 67, f. 11, dok. 1221, Izjava kapetana Ivana Mraka, 1; VA, P16, k. 49, f. 1, dok. 22, Izjava kapetana Dušana Šešlije, 43; Ž. Karaula, Bjelovarski ustanak - Dokumenti - dok. br. 65: Sjećanje poručnika Leopolda Suplančića na bjelovarske događaje od 7.-10. travnja 1941. godine, 141-142; Д. С. Крстић, н. д., 38.

${ }^{43}$ VA, P17, k. 8a, f. 2, dok. 39, Operacijski dnevnik Četvrte armije, 10; Z. Dizdar, n. d., 591. 
ke i tom prilikom dvojica pobunjenika su ubijena, ${ }^{44}$ dok su četvorica zarobljena i saslušana u štabu armije. Odmah posle ovog incidenta, štab armije je krenuo u Popovaču. ${ }^{45}$

Nakon što su se spojili, 108. i 40. peš. puk krenuli su putem kroz selo Prespu ka Bjelovaru. U Prespi ih je dočekao komandant Hrvatske građanske zaštite za Bjelovar, Fabijan Anatoljak. Pošto su odbili da sa njim pregovaraju o bilo čemu, pobunjenici su od njega zatražili da njihove zahteve prenese nadležnima u Bjelovaru. Dok je Anatoljak nosio zahteve pobunjenika u Bjelovar, njihova prethodnica je izbila na liniju Novoseljani-Minovac, gde je razvijena u borbeni položaj. Glavnina pobunjeničkih snaga zaustavila se kod sela Ždralova. Anatoljak je oko 10.00 časova došao u kontakt sa gradonačelnikom Bjelovara dr Julijem Makancem, kojem je predočio namere pobunjenika da krenu na Bjelovar. Makanec, koji se priklonio pobunjenicima, stavio je sebi u zadatak da pridobije i vojsku i žandarmeriju u Bjelovaru, kako bi pobunjenici u grad ušli „bez prolivanja krvi“. On je zajedno sa ustašom Ivanom Šestakom tražio predaju žandarma, dok je uz pomoć Franja Hegeduša, narodnog poslanika HSS-a, predaju tražio od vojske, tj. majora Topalovića koji je još uvek bio u Bjelovaru. Oba zahteva su odbijena, a major Topalović je tvrdio da se u blizini Bjelovara nalazi jedan lojalan puk i da će se vojska boriti do poslednjeg čoveka kako bi sačuvala svoju vojničku čast. Sa takvim odgovorom u pravcu pobunjenika krenulo je prvo gradsko izaslanstvo sastavljeno od: načelnika okruga Josipa Verhasa, istog onog koji je primio naređenje od generala Nedeljkovića da sa policijom održava red $\mathrm{u}$ gradu, pominjanog narodnog poslanika Franje Hegeduša, te ustaša Tome Funteka i Ivana Šestaka. Ovo izaslanstvo donelo je pobunjenicima vesti da je ,grad potpuno za njihov pokret i da će od građana biti srdačno dočekani“. Narednik Čvek je obavestio bjelovarsko gradsko izaslanstvo da je štabu Četvrte armije poslao ultimativni zahtev za predaju, ${ }^{46}$ a od pomenutog izaslanstva je zahtevao „da se žandarmerija i vojska, koja se nalazila u Bjelovaru razoruža, kao i da se grad mirno preda kako bi se izbeglo krvoproliće“. ${ }^{47} \mathrm{U}$ samom Bjelovaru, gradonačelnik Makanec je za ovo vreme naredio da se razoružaju

\footnotetext{
${ }^{44}$ Ubijeni su Milan Denčić i Mato Haniš.

${ }^{45}$ VA, P17, k. 8a, f. 2, dok. 39, Operacijski dnevnik Četvrte armije, 10; V. Terzić, $n$. d., II/334; Z. Dizdar, $n . d ., 591$.

${ }^{46}$ Kapetan Dušan Šešlija navodi u svojoj izjavi da je ovaj ultimatum, pod prinudom, svojom rukom pisao potpukovnik Vojislav Petrović, komandant 108. peš. puka. „Vođa pobunjenika“, koga kapetan Šešlija ne imenuje, diktirao je, a potpukovnik Petrović pisao. Po sećanju kapetana Šešlije, ultimatum je bio sledeće sadržine: „Komandantu mjesta Bjelovar - Pred Bjelovarom se nalazi oslobodilačka vojska oko 8.000 (ljudi). Tražimo odmah, da sva vojna lica, koja se nalaze u Bjelovaru, polože oružje u bjelovarskom parku. Sva nadleštva koja se nalaze u mestu imaju se staviti pod našu komandu - upravu. Ako pokušate da date bilo kakav otpor, varoš ćemo napasti i kao odmazda biće pobijena sva vojna lica, koja se tamo nalaze i sav srpski živalj.“ Komandant 108. peš. puka je na kraju ovoga lično dodao: „Ovo su zahtevi pobunjenih vojnika, čiji smo mi zarobljenici - potpukovnik Vojislav Petrović“". VA, P16, k. 49, f. 1, dok. 22, Izjava kapetana Dušana Š̌šlije, 41-42.

47 Ž. Karaula, Bjelovarski ustanak - Dokumenti, dok. br. 45: Potvrda kotarskog predstojnika Josipa Verhasa o sudjelovanju Ivana Čveka u ,bjelovarskom ustanku“, 81.
} 
stražari srpske nacionalnosti, što je i učinjeno. Sa 50 pušaka on je dodatno naoružao ustaše u samom gradu, a preko žandarmerijskog narednika Matije Navojca obavestio je žandarme Hrvate da budu spremni na borbu protiv „,̌etnika, vojnika i žandara u Bjelovaru“. Tako je i u samom gradu stvorena grupa koja je bila spremna na borbu. Makanec je, pošto je dobio ultimativni zahtev za predaju vojske u Bjelovaru, još jednom stupio u kontakt sa majorom Topalovićem i od njega tražio da se vojska preda inače će pobunjenici, kojih ima oko 8.000 i koji se nalaze na ivici grada, izvršiti napad na grad. Major Topalović je prvo pristao na pregovore, a zatim i na predaju. ${ }^{48} \mathrm{U}$ hrvatske ruke palo je oko 20 oficira $\mathrm{i}$ nekoliko stotina vojnika i žandarma. Istovremeno postavljena je straža na raskrsnicama, mostovima, ulicama, ali i svim važnijim objektima u gradu. Gradonačelnik Makanec odredio je kapetana Franju Hardija iz bjelovarskog vojnog okruga za komandanta mesta, i u zadatak mu stavio da preduzme sve radnje oko prihvata i smeštaja pobunjenih jedinica. Pored toga, on je naredio da se na sve kuće okače hrvatske zastave „u znak slaganja sa pobunjenicima““49

U međuvremenu, među pobunjenike je stigao i rezervni vazduhoplovni kapetan Ivan Mrak. Po tvrdnji poručnika Suplančića, koju u svom radu preuzima Zdravko Dizdar, tom prilikom je osnovan „mirovni komitet"“, čiji su članovi bili vojna i civilna lica. Na čelu ,komiteta“ bio je narednik Čvek, a članovi su bili: kapetan Mrak, poručnik Suplančić, gradonačelnik Makanec, narodni poslanici Franjo Hegeduš i Tomo Vojković, načelnik okruga Josip Verhas, gradski odbornici Robert Vagner i Tomo Funtek, te zapovednik Građanske zaštite Fabijan Anatoljak. Prva odluka „mirovnog komiteta“ bila je izbor kapetana Ivana Mraka za komandanta cele pobunjeničke vojske, što je ovaj i prihvatio. ${ }^{50}$ Isti taj kapetan, u izjavi koju je dao organima NDH već 18. aprila 1941, ne pominje postojanje ovog „komiteta“, ali navodi: „Zapovjednici pobune izabrali su me za svoga vrhovnog zapovjednika, o čemu su odmah obavjestili vojnike“. ${ }^{51}$ Slično njemu, ni narednik

\footnotetext{
${ }^{48}$ Velimir Terzić, ne navodeći izvor, piše da je ultimatum odbijen i da su pobunjenici preduzeli napad na grad, te da je slaba odbrana Bjelovara morala kapitulirati, kada je zarobljeno „,više oficira i nekoliko stotina vojnika“ (V. Terzić, $n$. d., II/334-335). S druge strane hrvatski istoričar Zdravko Dizdar, pozivajući se na izjavu Makaneca od 22. aprila 1941, piše da je major Topalović prihvatio pregovore i da je odlučio da se preda i da se predalo ukupno „oko 100 oficira i nekoliko stotina vojnika i žandara“ (Z. Dizdar, n. d., 594). U prilog ovoj drugoj tvrdnji idu i izjave oficira koje smo imali na raspolaganju. U izjavi kapetana Ivana Mraka, koji je pred ulazak pobunjenika u Bjelovar preuzeo komandu nad njima, možemo pročitati da se Bjelovar predao te da su pobunjenici u grad ušli bez borbe (VA, P17, k. 67, f. 11, dok. 1221, Izjava kapetana Ivana Mraka, 2). Nikakvu borbu ne pominje ni kapetan Dušan Šešlija u svojoj izjavi, niti major Dobroslav Krstić u svom „ratnom dnevniku“. Kapetan Šešlija navodi sledeće reči majora Topalovića koji se obraćao „,vođi“ pobunjenika, a koga kapetan Šešlija ne imenuje: „E, gospodine, ja sam ispunio svoju reč, sad je red na vas da mi omogućite da sa predatim (istakao autor) oficirima, koliko nas ovde ima u gradu, odlazak za Zagreb.“ (VA, P16, k. 49, f. 1, dok. 22, Izjava kapetana Dušana Šešlije, 45).

49 VA, P17, k. 67, f. 11, dok. 1221, Izjava kapetana Ivana Mraka, 2; V. Terzić, n. d., II/334-335; Z. Dizdar, $n$. d., 592-594.

${ }^{50}$ Z. Dizdar, $n$. d., 595-596.

${ }^{51}$ VA, P17, k. 67, f. 11, dok. 1221, Izjava kapetana Ivana Mraka, 2.
} 
Čvek ne pominje postojanje ovog komiteta, već samo kaže da je kapetan Mrak izabran za zapovednika cele pobunjeničke vojske u Bjelovaru. ${ }^{52}$

I u jednom i u drugom slučaju, sa ili bez postojanja ovog ,mirovnog komiteta“, pred novim komandantom pobunjenika stajalo je nekoliko zadataka. Prvi od njih bio je odvesti pobunjenike u Bjelovar, što je on bez oklevanja i učinio. U grad je prvo ušla prethodnica, a zatim nešto pre 17.00 časova i glavnina pobunjene vojske. Pobunjenici su u grad ušli u stroju. Neki od zarobljenih srpskih oficira, iz pobunjeničke kolone, nadali su se da će pobunjenici u gradu naići na otpor, međutim na njihovo razočaranje naišli su na ulice okićene hrvatskim zastavama i na oduševljeno more ljudi, koji su klicali „Živjela Slobodna Hrvatska“ i „Živio Ante Pavelićc“ i srećno dočekivali svoje „oslobodioce“. U 18.00 časova sa balkona gradske skupštine, gradonačelnik Makanec proglasio je pred okupljenim vojnicima i građanstvom, ,uskrsnuće Nezavisne Države Hrvatske“ ${ }^{53}$ što je naišlo na buru oduševljenja među prisutnima. ${ }^{54}$

Sledeći zadatak koji je stajao pred kapetanom Ivanom Mrakom bio je osiguranje Bjelovara. Pobunjenici su iz tog razloga prvo zauzeli sve vojne zgrade u gradu, kao i železničku stanicu, a zatim izvršili posedanje položaja oko grada. Južno od Bjelovara na liniju Veliko Sredice - Korenovo - Novoseljani upućena su „dva bataljona“ pod komandom narednika Čveka. Zapadno od Bjelovara na liniju Plavnice-Hrgovljani poslan je ,jedan bataljon sa dve mitraljeske čete" pod komandom narednika-vodnika Jembri Zvonimira. Severoistočno od Bjelovara na liniju Ivanovčani-Markovac upućen je ,jedan bataljon“ pod komandom podnarednika Vilima Retkovića. Kao neka vrsta borbenog osiguranja, a zbog vesti da je prema Bjelovaru upućen Četvrti jurišni bataljon, postavljen je jedan odred ispred Korenova. Za komandanta unutrašnjeg osiguranja grada određen je poručnik Suplančić. Kapetanu Mraku se u Bjelovaru javio još jedan oficir, konjički kapetan Zvonimir Sirovatka, koji mu je pomogao u radu. ${ }^{55}$

Deo zarobljenih oficira, kako onih iz štaba Četvrte armije, tako i onih iz 108. i 40. peš. puka, bio je smešten u gradskoj skupštini (vijećnici), a deo u zgradi bjelovarskog vojnog okruga. U zgradi gradske skupštine bilo je ukupno 46 oficira, a između ostalih i komandanti pobunjenih pukova, potpukovnici Vojislav Petrović i Ljubomir Saković. Sa njima je bio i major Topalović iz štaba

52 Ž. Karaula, Bjelovarski ustanak - Dokumenti, dok. br. 52: Izviješće vođe „bjelovarskog ustanka" narednika Ivana Čveka o travanjskim danima u Bjelovaru i okolici, 104.

53 Makanec je u oktobru 1941. o ovome zapisao: „Na ovom dijelu svete hrvatske zemlje, oslobođene vlastitom snagom i akcijom, iza leđa srpske fronte, koja se tada još nije bila započela raspadati, u podpunoj neizvijesnosti, šta će nam donijeti sutrašnjica, mi smo iz dubine duše osijećali divotu i zanos apsolutne slobode i neizvijesnosti. Eto, makar jedan dan, makar nekoliko dana, pa onda neka bude s nama, što hoće i mora - ali moći ćemo reći, da nije bilo nad nama gospodara do Boga. Svuda oko nas metež i neizvijesnost, svuda oko nas srpske čete, koje su zauzele sumnjivo držanje, a Bjelovar i njegova okolica svega nekoliko kilometara promjera: MI SMO NEZAVISNA DRŽAVA HRVATSKA! (istaknuto u originalu). “ Citirano prema: Z. Dizdar, $n$. d., 596.

${ }^{54}$ VA, P17, k. 67, f. 11, dok. 1221, Izjava kapetana Ivana Mraka, 2; Д. С. Крстић, н. д., 39; V. Terzić, $n$. d., II/335; Z. Dizdar, n. d., 596.

${ }^{55}$ VA, P17, k. 67, f. 11, dok. 1221, Izjava kapetana Ivana Mraka, 2. 
Četvrte armije. On je od pobunjenika tražio da se svim zarobljenim oficirima omogući odlazak u Zagreb, onako kako je on to dogovorio prilikom pregovora o predaji. Pošto su pobunjenici odugovlačili sa odgovorom na ova traženja majora Topalovića i nisu puštali zarobljene oficire, on je zahtevao da dobije vezu sa komandantom Prve grupe armije generalom Petrovićem, ali je taj njegov zahtev odbijen. Umesto smanjenja broja zarobljenika i odlaska zarobljenih oficira $\mathrm{u}$ Zagreb u toku noći 8/9. aprila broj zarobljenika se povećao. Naime na železničkoj stanici u Bjelovaru zaustavljen je voz u kome se nalazila vojska. Oficiri i vojnici srpske nacionalnosti su zarobljeni, a Hrvati su se pridružili pobunjenicima. Zarobljeni oficiri su, uprkos svim traženjima da im se omogući odlazak u Zagreb, ostali u Bjelovaru tokom cele noći. ${ }^{56}$

Pobunjenim delovima Slavonske divizije koji su se nalazili u Bjelovaru, izjutra 9. aprila obratio se i Vlatko Maček. Već u toku prethodnog dana, kada je general Petrović obavestio Vrhovnu komandu o pobuni 108. peš. puka, njemu je saopšteno da će Maček, koji se tada nalazio u Zagrebu, lično stupiti u kontakt sa pobunjenim pukom i uticati da se ovaj vrati redu i disciplini. Mačekova misija trebalo je, konačno, da dovede do toga da se pobunjeni puk vrati na front i počne borbu sa nemačkim jedinicama. ${ }^{57}$ Pored toga, Mačeku se u toku noći 8/9. aprila lično obratio i komandant Četvrte armijske oblasti (ratne) general Pantelija Jurišić, zamolivši ga da apeluje na pobunjenike da se vrate na front. Najzad, Maček je ujutru 9. aprila nazvao telefonom Bjelovar i razgovarao sa narodnim poslanikom iz HSS-a, Franjom Hegedušom. Hegeduš je obavestio predsednika svoje stranke o stanju u Bjelovaru, a Maček je od njega tražio da, zajedno sa drugim predstavnicima HSS-a, utiče na pobunjenike kako bi se vratili na front. Maček je, uz to, pobunjenicima uputio i svog izaslanika, izvesnog Kovača. U pismu koje je ovaj doneo u Bjelovar, Maček je pozivao pobunjenike da se vrate na položaj i jamčio da im se ništa neće dogoditi. Pobunjenici su oko 12.00 časova pozvali Mačeka i saopštili mu da se njegovim traženjima ne može udovoljiti zato što „svaki vojnik izjavljuje da neće da se bori za srpsku vladu protiv prijateljskog njemačkog naroda i vojske“. Nakon ovoga Maček i Zvonimir Sirovatka, koji je u ime pobunjenika razgovarao telefonom sa Mačekom, ušli su u kraću prepirku koja je završena Mačekovim rečima da on smesta dolazi u Bjelovar kako bi uspostavio red među pobunjenicima. Ali, opet nije došao. Umesto njega stigao je njegov drugi izaslanik, Đuro Kemfelja. ${ }^{58}$ I ovaj Mačekov izaslanik je, kao i njegov prethodnik, nosio pismo u kome se zahtevalo da se pobunjeni pu-

\footnotetext{
${ }^{56}$ VA, P16, k. 49, f. 1, dok. 22, Izjava kapetana Dušana Šešlije, 44-47; Д. С. Крстић, н. д., 3940; Z. Dizdar, $n$. d., 597.

${ }^{57}$ VA, P17, k. 5, f. 1, dok. 5, Izjava armijskog generala Milorada Petrovića, 21; V. Terzić, n. d., II/334.

${ }^{58}$ Kemfelja se obratio zarobljenim oficirima koji su se tada još uvek nalazili u gradskoj skupštini, rekao im da ga šalje Maček, koji će, kako im je tada saopštio, u najskorije vreme i sam doći u Bjelovar. Samouvereno im je kazao i to: „Da se ne treba ničeg bojati, da će sve biti u redu i da će se vojnici vratiti (na položaje - prim. aut.)“. VA, P16, k. 49, f. 1, dok. 22, Izjava kapetana Dušana Šešlije, 53.
} 
kovi vrate na front. Rezultat je bio isti - zahtev je ponovo odbijen. ${ }^{59} \mathrm{Na}$ taj način Vlatko Maček, koji je bio neprikosnoveni vođa HSS-a i hrvatskog naroda duže od jedne decenije, nije uspeo da deluje na pobunjenike u cilju njihovog vraćanja na front. Iako je obećavao da će lično doći u Bjelovar, što je zbog položaja koji je zauzimao i ličnog autoriteta koji je posedovao morao učiniti, on se nije pojavio među pobunjenicima, već im je slao izaslanike koji niti su imali autoritet za rešavanje ove situacije niti su bili kadri da je reše, ako je to uopšte 9 . aprila ujutru i bilo moguće učiniti.

Ni ban Banovine Hrvatske, dr Ivan Šubašić, nije imao više uspeha. On je u isto vreme kada i Maček telefonom razgovarao sa pobunjenicima u Bjelovaru i tom prilikom tražio od njih da se vrate na položaje, ,jer se na Dravi nalaze samo slabe njemačke čete“. Tom prilikom on je pobunjenicima skrenuo pažnju da će ukoliko odbrana Bjelovara popusti on biti nemoćan da ih zaštiti, te da će u tom slučaju Bjelovar „,biti prepušten na milost i nemilost srpskoj kaznenoj ekspediciji“. Kao i Mačekov, pobunjenici su odbili i Šubašićev zahtev. ${ }^{60}$

Pored njih dvojice tog jutra je sa pobunjenicima u Bjelovaru posredstvom telefonske veze govorio i general Nedeljković. On im je tada zapretio da će bombarderska avijacija uništiti Bjelovar, ukoliko se grad odmah ne preda i pobunjenici ne vrate na front. Osim toga general Nedeljković je najenergičnije tražio da se svi zarobljeni oficiri Srbi i Slovenci odmah upute u Zagreb. Prva dva zahteva o predaji i vraćanju na front su i pored pretnje bombardovanjem odbijena. Treći zahtev o upućivanju zarobljenih oficira u Zagreb je posle konsultacija među pobunjenicima usvojen. Od strane zarobljenih oficira date su im garancije da će se pratnja vratiti u Bjelovar. Autobus ${ }^{61}$ sa 37 zarobljenih oficira, pod pratnjom jednog kamiona i dva automobila koji su bili okićeni hrvatskim zastavama, krenuo je posle podne put Zagreba. Za vreme dok su zarobljeni oficiri ulazili u autobus, masa ispred gradske skupštine zahtevala je da se oni ne šalju u Zagreb i tražila njihove glave. Najzad, kada je autobus krenuo zaustavljen je još jednom na samom izlasku iz Bjelovara. Pobunjenici koji su zaustavili kolonu, zahtevali da zarobljeni oficiri napuste autobus. Posle 15-minutne rasprave između pobunjenika koji su zaustavili kolonu i pobunjenika koji su bili u pratnji zarobljenih oficira, kolona je nastavila pokret i oko 19.00 časova stigla u Zagreb u štab Prve grupe armija. ${ }^{62}$

Tokom 9. aprila, glavni zadatak pobunjenika u Bjelovaru bio je da uspostave vezu sa Nemcima i odbrane grad od eventualnih napada regularnih jugoslovenskih jedinica. Gradonačelnik Makanec pokušao je da uspostavi direktnu radio vezu sa nemačkim jedinicama, ali u tome nije uspeo. Kapetan Dušan Šešlija piše u svojoj izjavi da je, pre nego što su oficiri upućeni u Zagreb, čuo Makaneca kako

\footnotetext{
${ }^{59}$ VA, P16, k. 49, f. 1, dok. 22, Izjava kapetana Dušana Šešlije, 53; Z. Dizdar, $n$. d., 599.

${ }^{60}$ Z. Dizdar, $n$. d., 600.

${ }^{61}$ Zdravko Dizdar u navedenom radu pominje da su zarobljeni oficiri za Zagreb upućeni vozom, ali smo u izjavama zarobljenih oficira na više mesta pronašli podatak da su oficiri u Zagreb ipak otputovali autobusom. Z. Dizdar, $n . d ., 600$.

${ }^{62}$ VA, P16, k. 49, f. 1, dok. 22, Izjava kapetana Dušana Šešlije, 54-56; Д. С. Крстић, н. д., 41; V. Terzić, $n$. d., II/349; Z. Dizdar, $n$. d., 600.
} 
telefonom nekome govori: „Možete slobodno doći, sve su prepreke sa puteva i mostova sklonjene. Bjelovar je u našim rukama!“" Kapetan Šešlija pretpostavlja da se radi o nekom nemačkom komandantu. ${ }^{63}$ Velimir Terzić u svojoj monografiji preuzima ovu izjavu kapetana Šešlije, ali tom prilikom Makanecovog sagovornika identifikuje kao nemačkog oficira, prenebregavajući činjenicu da je to bila Šešlijna pretpostavka. ${ }^{64}$ Međutim, prema podacima koje u svojoj izjavi daje vođa pobunjenika kapetan Ivan Mrak ovoga dana veza sa Nemcima nije bila uspostavljena. Pa sa kim je onda gradonačelnik Makanec razgovarao telefonom? U Bjelovar je u toku ovog dana, a posle pomenutog telefonskog razgovora gradonačelnika Makaneca i ,nepoznatog Nemca“, na srpsko-hrvatskom jeziku, iz Velike Pisanice stigao Jozef Štrumpf, folksdojčer i član Kulturbunda, koga je kapetan Mrak uvrstio u parlamentarnu delegaciju ${ }^{65}$ koju je poslao prema Dravi kako bi uspostavila vezu sa Nemcima. Ova delegacija se, međutim, vratila u Bjelovar neobavljenog posla. ${ }^{66}$ Mi smo iz ovog razloga skloni da verujemo da Makanec nije razgovarao ni sa kakvim nemačkim komandantom, već upravo sa J. Štrumpfom, jer bi kapetan Mrak znao i u svojoj izjavi, koju piše već u aprilu 1941, što znači nekoliko dana posle događaja o kojima govori, sigurno napisao da je veza sa Nemcima uspostavljena u toku 9. aprila. ${ }^{67}$

Sta je bilo sa drugim zadatkom, tj. obezbeđenjem Bjelovara od eventualnih napada? Bjelovarski pobunjenici su imali informacije da ,jaki motorizovani odredi“" iz Grđevca kreću prema Bjelovaru i da je to ta „kaznena ekspedicija“ o kojoj im je govorio ban Šubašić. Pored toga u gradu su se čuli glasovi da su šume pune četnika, te da je Četvrti jurišni (četnički) bataljon krenuo iz Karlovca kako bi ugušio pobunu. Prema ovim ,jakim motorizovanim odredima“ odmah je upućena jedna grupa koja je imala zadatak da ih upozori da se u Bjelovaru nalazi dobro organizovana i naoružana ,pobunjena hrvatska vojska“, te da će u slučaju da se približe gradu nastati krvoproliće. Ova tzv. kaznena ekspedicija nije ni krenula prema Bjelovaru, i nije nam poznato da li je uopšte došlo do kontakta između pobunjeničke grupe, koja je imala zadatak da pregovara, i nekih jugoslovenskih jedinica, ali su pobunjenici, za svaki slučaj, minirali puteve koji su od Grđevca vodili ka Bjelovaru. ${ }^{68}$ Što se tiče Četvrtog jurišnog bataljona, ovaj se već od noći

${ }^{63}$ VA, P16, k. 49, f. 1, dok. 22, Izjava kapetana Dušana Šešlije, 52.

${ }^{64} \mathrm{~V}$. Terzić, $n$. $d$., II/349.

65 Pored njega, članovi parlamentarne delegacije koja je imala zadatak da uspostavi vezu sa Nemcima bili su: Stjepan Nik, gradski finansijski savetnik, major Ivan Medvedović, vatrogasac Drabika i šofer Ivančević.

${ }^{66}$ VA, P17, k. 67, f. 11, dok. 1221, Izjava kapetana Ivana Mraka, 3; Z. Dizdar, n. d., 601.

${ }^{67}$ Ovakvu našu tvrdnju dodatno učvršćuje i izjava narednika Ivana Čveka koji kaže: „9. travnja nastali smo svim silama da dođemo u dodir sa Njemačkim trupama, gdje se je mnogo istaknuo gradonačelnik Dr. Julije Makanec, koji je mene i g. Mraka upoznao sa vođom Njemaca mlinarom Štrupfom iz Velike Pisanice, kojega smo odmah primili i zajedno vijećali: G. Mrak, ja i Dr. Makanec, te smo ga zamolili da omogući vezu sa Njemcima. [...] [Mi] smo pokušavali iz radio postaje da dobijemo, ali nijesmo mogli.“ Ž. Karaula, Bjelovarska pobuna-Dokumenti, dok. br. 52: Izvješće vođe „bjelovarskog ustanka“ narednika Ivana Čveka o travanjskim danima u Bjelovaru i okolici, 105-106.

${ }^{68}$ VA, P17, k. 67, f. 11, dok. 1221, Izjava kapetana Ivana Mraka, 2; Z. Dizdar, n. d., 600. 
4/5. aprila nije nalazio u Karlovcu, kako su to pobunjenici mislili, već u Đurđevcu gde je bio pod neposrednom komandom komandanta Četvrte armije, generala Nedeljkovića. Budući da je znao da je ovaj bataljon zahvatila jaka ustaška propaganda, general Nedeljković nije ni nameravao da ga upotrebi za gušenje bjelovarske pobune. Da je bataljon bio zahvaćen takvom propagandom, pokazalo se već sutradan, 10. aprila, kada se njegov veći deo predao Nemcima. ${ }^{69}$

Izjutra 10. aprila, dok su preostale jedinice Slavonske divizije vodile borbu sa Nemcima u rejonu sela Pčelića, bjelovarski pobunjenici su uspeli da uspostave vezu sa nemačkim jedinicama. Opet je prema Nemcima upućena parlamentarna delegacija u sastavu: major Ivan Medvedović, ${ }^{70}$ kapetan Ivan Grdelj, narednik Ivan Čvek, Jozef Štrumpf, predstavnik Kulturbunda, Stjepan Nik, gradski finansijski savetnik iz Bjelovara i Luka Starčević, kao predstavnik HSS-a. Ova delegacija naišla je kod Đurđevca na nemačku prethodnicu, koja ih je razoružala i uputila u selo Kloštar. Tu ih je primio jedan nemački komandant, verovatno pukovnik Jesert, koga su parlamentarci informisali o stanju u Bjelovaru. Posle toga parlamentarci su zajedno sa Nemcima krenuli put Bjelovara, $u$ koji su nemačke jedinice počele da ulaze oko 12.00 časova. Građani Bjelovara, pobunjenici i gradske vlasti na čelu sa gradonačelnikom Makanecom, oduševljeno su dočekali Nemce. ${ }^{71}$ Kada je nekoliko sati kasnije Slavko Kvaternik u Zagrebu proglasio stvaranje Nezavisne Države Hrvatske, Makanec je zaključio da su tim činom bjelovarski pobunjenici ,,prestali biti buntovnici i postali organi hrvatske državne vlasti“‘. 72

\section{Zaključak}

Bjelovarska pobuna je bila unapred isplanirana, organizovana i izvedena od strane ustaša i njihovih pristalica. Izvedena je u vreme Aprilskog rata, kada su spoljnopolitički uslovi bili povoljni za njenu realizaciju i kao takva ona je eklatantan primer vojničke neposlušnosti i nediscipline. Ako je posmatramo iz ugla pozitivnog zakonodavstva Kraljevine Jugoslavije, ona je nesporno predstavljala i izdaju države.

Pobuna dela jedinica Slavonske divizije bila je plod složenih političkih i društvenih prilika koje su vladale u Kraljevini Jugoslaviji u predvečerje Aprilskog rata, pre svega nerešenog nacionalnog pitanja i 20-godišnjeg političkog nerazumevanja između glavnih političkih predstavnika hrvatskog i srpskog naroda. Ipak, ona je primarno bila uzrokovana željom dela hrvatskog naroda da se odvoji od jugoslovenske kraljevine i formira samostalnu i nezavisnu državu.

${ }^{69}$ Aleksandar Životić, „Četničke jedinice Vojske Kraljevine Jugoslavije u Aprilskom ratu“, Vojnoistorijski glasnik, br. 1-2, (2003), 44.

${ }^{70}$ Kapetan Mrak u svojoj izjavi identifikuje ovog majora kao Medvedovića, i to dva puta, dok ga Zdravko Dizdar identifikuje kao Medvedeca.

71 VA, P17, k. 67, f. 11, dok. 1221, Izjava kapetana Ivana Mraka, 3; Ž. Karaula, Bjelovarska pobuna - Dokumenti, dok. br. 52: Izvješće vođe ,bjelovarskog ustanka“ narednika Ivana Čveka o travanjskim danima u Bjelovaru i okolici, 106-107; Z. Dizdar, n. d., 603.

${ }^{72}$ Citirano prema: Z. Dizdar, $n$. d., 603. 
Značaj bjelovarske pobune se ogleda u tome što je to bila prva organizovana akcija ustaša u Aprilskom ratu, pre proglašenja NDH 10. aprila 1941, koja je imala uspeh i bila podržana od širih masa. Njihove ostale akcije izvedene pre 10. aprila bile su sporadične i nisu dale veće rezultate. Ne može se reći da je bjelovarska pobuna uticala na to da se u Banovini Hrvatskoj organizuje širi „ustaški ustanak“. On se rasplamsao tek kao posledica proglašenja NDH u Zagrebu, posle čega su ustaše uz pomoć nemačke i italijanske vojske počele da preuzimaju vlast na teritoriji koju su označili kao svoju.

\section{REFERENCE}

- Aprilski rat 1941, Zbornik dokumenata, knjiga 2. Priredio Antun Miletić. Beograd: Vojnoistorijski institut, 1987.

- Bjelajac, Mile. „Savska divizija u Aprilskom ratu“. Vojnoistorijski glasnik, br. 1, (1991), 125-158.

- Boban, Ljubo. Maček i politika HSS 1928-1941. Iz povijesti hrvatskog pitanja, I-II. Zagreb: Liber, 1974.

- Dimić, Ljubodrag. Srbi i Jugoslavija - prostor, društvo i politika. Beograd: Stubovi kulture, 1998.

- Dimić, Ljubodrag. Istorija srpske državnosti. Knjiga 3 - Srbija u Jugoslaviji. Novi Sad: Srpska akademija nauka i umetnosti - Ogranak u Novom Sadu, Beseda, Društvo istoričara južnobačkog i sremskog okruga, 2001.

- Dizdar, Zdravko. „Bjelovarski ustanak od 7. do 10. travnja 1941“. Časopis za suvremenu povijest, br. 3, (2007), 581-609.

- Dobrivojević, Ivana. „Prilog proučavanju sučeljenih percepcija. Hrvati i Srbi o Kraljevini Jugoslaviji“. Tokovi istorije, br. 3, (2009), 189-206.

- Drugi svetski rat (pregled ratnih operacija). Događaji od početka rata do 22. juna 1941. Beograd: Vojnoistorijski institut JNA, 1957.

- Gulić, Milan. „Važnost Dunava i Đerdapa u ratnim operacijama na području Jugoslavije 1941-1944“. Istorija 20. veka, br. 3, (2012), 37-62.

- Jovanović, Slobodan. Jugoslovenska misao u prošlosti i budućnosti. Beograd: Sloboda, 1939.

- Karaula, Željko, priređivač. Bjelovarski ustanak 7.-10. travnja 1941. u povijesnim izvorima - Dokumenti. Bjelovar: Viatoni, 2012.

- Krstić, Dragoslav S. „Bjelovar 1941. - iz mog ratnog dnevnika“. Glasnik SKID „Njegoš“, sv. 23, (1969).

- Milak, Enes. „Dokument italijanskog Kraljevskog poslanstva u Beogradu o bombardovanju Beograda aprila 1941. godine“. Vojnoistorijski glasnik, br. 1, (1988), 354-360.

- Miletić, Marko B. „Pokušaj odbrane istočne Makedonije u Aprilskom ratu 1941“. Vojnoistorijski glasnik, br. 1, (2015), 238-262.

- Miletić, Marko B. „Dravska banovina u Aprilskom ratu 1941. godine“. Prispevki za novejšo zgodovino, 2, (2018), 85-109. 
- Radojević, Mira. „Demokratska stranka o državnom preuređenju Kraljevine Jugoslavije 1935-1939“. Istorija 20. veka, br. 1-2, (1991), 37-63.

- Račić, Nikola. Istočna Srbija u ratu i revoluciji 1941-1945 (hronologija). Zaječar: Međuopštinska konferencija SKS, Istorijski arhiv Timočke krajine, 1984.

- Stefanovski, Mirjana. Ideja hrvatskog državnog prava i stvaranje Jugoslavije. Beograd: Draganić, 1995.

- Terzić, Velimir. Slom Kraljevine Jugoslavije 1941. Uzroci i posledice poraza, I-II. Beograd, Ljubljana, Podgorica: Narodna knjiga, Partizanska knjiga, Pobjeda, 1982.

- Životić, Aleksandar. „Četničke jedinice Vojske Kraljevine Jugoslavije u Aprilskom ratu“. Vojnoistorijski glasnik, br. 1-2, (2003), 39-47.

MARKO B. MILETIĆ, MA, Research Assistant

Institute for Contemporary History

Belgrade, Republic of Serbia

marko.miletic1990@gmail.com

\section{THE BJELOVAR REBELLION IN THE 1941 APRIL WAR}

\section{Summary}

The paper analyzes and reconstructs the course of the Bjelovar rebellion in the April War [the invasion of the Kingdom of Yugoslavia by the Axis powers]. The Bjelovar rebellion was planned, organized, and carried out by the Ustashas and their supporters during the April War, when foreign policy conditions were favorable for its realization. As such, it is an eclectic example of military disobedience and insubordination. If we look at it from the perspective of the positive legislation of the Kingdom of Yugoslavia, it undoubtedly represented a betrayal of the state. The importance of the Bjelovar rebellion is reflected in the fact that it was the first organized action by the Ustashas, before the proclamation of the Independent State of Croatia on April 10, 1941, which was a success and was supported by the masses. The Bjelovar rebellion was the result of complex political and social circumstances that prevailed in the Kingdom of Yugoslavia on the eve of the April War, primarily an unresolved national issue and a 20-year political misunderstanding between the main political representatives of the Croatian and Serbian people. However, it was primarily caused by the desire of a part of the Croatian people to separate from the Yugoslav kingdom and form an independent state.

KEYWORDS: Bjelovar, Rebellion, Kingdom of Yugoslavia, April War, Independent State of Croatia, Slavonska division 